\title{
Minat dan Bakat Mahasiswa Dakwah Pada Kegiatan Khithabah
}

\author{
Jujun Junaedi \\ UIN Sunan Gunung Djati Bandung \\ E-mail: daijun@yahoo.com
}

\begin{abstract}
Khithabah as part of sermons, including one method of propagation in the context of mass communication that preachers often do. Khithabah become a popular paradigm that the escort mission dynamics of mass media propaganda with all kedakwahannya effectiveness. Often khithabah conducted limited spread Islamic ideology which incidentally is the transfer of ideas with a bunch of speeches recreational bandage which in turn offers the essence of propaganda about itself. However, the insertions are not rare in any recreational activity khithabah a bargaining power for their own propaganda and a lover of excellence in the Islamic world that in fact describe the nature of grace for the whole of nature.
\end{abstract}

\section{Kata kunci:}

Khithabah, Budaya Populer, Motif Diri, Media Massa

\section{A. Pengantar}

Problematika dakwah saat ini begitu kompleks. Kompleksitas kedakwahan yang ada mengarah pada realitas kebermaknaan akan pemahaman agama yang menyulut pada satu tanda tanya besar yakni, bagaimana melaksanakan dakwah yang mendeskripsikan rahmat universal dalam berbagai aspek kehidupan. Pasalnya, dakwah yang selama ini dijalankan oleh segolongan umat Islam baru sebatas dakwah golongan yang ditujukan pada satu golongan tertentu dengan cara, karakter dan kultur yang ada pada golongan tersebut. Artinya, dakwah universal masih harus terus digalakan supaya cita-cita menebarkan kedamaian di muka bumi ini terlaksana sesuai dengan apa yang diharapkan. Dimana manusia seutuhnya faham dengan dakwah Islamiyah 
dan siap melaksanakan konsekuensi yang tercipta dari apa yang mereka lakukan.

Madjid (2010: 35) merekomendasikan format dakwah dalam konteks keindonesiaan yang dalam pandangannya sesuai dengan konstruksi cultural bangsa Indonesia. Formatif konstruktif yang ia tawarkan berupa imagologis dakwah multicultural yang sesuai dengan bingkai bangsa Indonesia. Formulasi tersebut sebagai refleksi surah Al'Ashr ayat 3 bahwa "dakwah yang seharusnya dilakukan ialah internalisasi doktrin keimanan pada setiap individu ditindaklanjuti melalui integritas sosial secara kolektif sebagai upaya pengaktulaisasian kepeduliaan sosial di tengah realitas keumatan." Spirit keumatan ini yang seyogiannya menjadi landasan pacu seorang da'i dalam konteks apapun untuk melangsungkan upaya penebaran benih-benih Islam sebagai rahmat semesta.

Dewasa ini, sebagaimana ruh dakwah yang tertuang dalam surah an-Nahl ayat 125 memberikan gambaran jelas tentang metode, cara berfikir dan bertindak dalam pelaksanaan dakwah. Antara hikmah, mauidzah hasanah dan Mujadalah tentunya mempunyai spirit tersendiri sebagai bagian dari cara kita menyebarkan pesan-pesan keIslaman di muka bumi ini. Pesan keIslaman apapun dan dengan cara bagaimanapun kita ssampaikan nilai substansial yang harus mengawal itu semua adalah nilai Amar Ma'ruf Nahyi Munkar. Kedua nilai ini yang menjadi pijakan seseorang dalam melaksanakan dakwah keIslamannya. Sebagaimana uraian Murtadha Muthathhari daam bukunya Stop Anarkisme bahwa para imam ahlubait dalam melaksankan kewajiban Tuhannya senantiasa diniatkan sebagai usaha untuk menyeru kepada kebaikan dan mencegah perbuatan yang munkar (Muthahhari, 2006: 37-40).

Khithabah sebagai bagian dari upaya tabligh, termasuk salah satu metode dakwah dalam konteks komunikasi massa yang seringkali da'i lakukan. Khithabah menjadi satu paradigma dakwah yang populer yang mengawal dinamika dakwah media massa dengan segenap efektivitas kedakwahannya. Seringkali khithabah yang dilakukan sebatas penyebaran ideologi keislaman yang notabene bersifat transfer gagasan sengan balutan pidato rekreatif yang pada akhirnya kurang menawarkan esensi dakwah itu sendiri. Namun, tak jarang pula adanya sisipan rekreatif dalam setiap kegiatan khithabah menjadi daya tawar tersendiri bagi mereka pecinta dakwah dan menjadi keunggulan dalam 
mendeskripsikan dunia Islam yang notabene bersifat rahmat bagi seluruh alam.

Agaknya, melalui kegiatan khithabah ini kita bisa menilai bagaiamana efektivitas dakwah yang bisa da'i lakukan dalam upaya transfer gagasan keIslaman. Khithabah selain bersifat massif juga berdonasi relatif cepat dalam menjangkau kontektualitas madh'u. Selain itu, kita bisa menilai tingginya zeitgeist (spirit) akan informasi keIslaman bagi masyarakat Indonesia, sehingga aktivitas khithabah mengalami peningkatan yang cukup signifikan. Faktanya, kita bisa melihat fenomena munculnya da'i-da'i di berbagai media massa yang kerap mengisi kajian seputar informasi keIslaman dengan gaya dan karakter pembawaan khithabahnya masing-masing. Sayangnya, kehausan informasi keIslaman tersebut kurang diiringi dengan penyediaan tenaga da'i profesional yang ahli dan mempunyai kapasitas di bidangnya. Estafeta atau regenerasi da'i ini harus terus digalakan sebagai upaya pengejawantahan nilai-nilai spirit amar ma'ruf nahyi munkar di kalangan muda.

Problematika seputar khithabah menjadi kajian yang cukup menarik. Pasalnya, intensitas dan peningkatan kebutuhan akan informasi keIslaman di kalangan masyarakat pada umumnya kurang teriringi dengan penyediaan dan regerasi da'i profesional. Baru sebatas da'i yang di minati masyarakat pada umumnya. Sementara di kalangan muda sendiri kurang mendapat perhatian yang lebih terhadap kegiatan khithabah ini. Maka dari itu, melalui tulisan ini, penulis mencoba mengamati frekuensi minat dan bakat mahasiswa dakwah terhadap kegiatan khithabah yang notabene menjadi core dan keahlian mereka secara akademik dan profesional. Tulisan ini tiada lain sebagai upaya penulis untuk menjunjung tinggi nilai amar ma'ruf nahyi munkar dalam kegiatan khithabah. Di samping upaya penulis dalam meregenerasikan tenaga da'i profesional yang sesuai harapan, sesuai cara fikir dan tindakan seorang da'i, utamanya sesuai dengan diktum Islam yakni AlQur'an dan Al-Hadits.

\section{B. Dakwah: Antara Harapan dan Kenyataan}

Emha Ainun Nadjib pernah berujar bahwa dakwah yang seharusnya kita lakukan adalah dakwah yang sesuai dengan kesadaran ruang dan waktu. Kesadaran ruang dan waktu seringkali kita pahami sebagai berdakwah sesuai kadar pengetahuannya (Nadjib, 2007: 68). Bagaimana kecerdasan seorang da'i diuji untuk menyampaikan pesan 
dakwahnya sesuai dengan realitas madh'u yang ia hadapi. Tentunya antara satu madh'u dengan madh'u yang lainnya mempunyai kultur, adat-kebiasaan dan tingkat pemahaman yang berbeda. Makanya, kepiawaian dan kepekaan seorang da'i menjadi ukuran dalam melaksanakan dakwah. Sukses-tidaknya sebuah upaya dakwah tergantung dari kesinambungan pesan yang disampaikan da'I dengan keselarasan tindakan dan cara fikir madh'u dalam mengelola pesan dakwah tersebut. Apakah baru sebatas wacana teoritis ataukah sudah mengarah pada wacana praktis dalam bertindak dan berbuat.

Sejatinya, orientasi dakwah yang kita sampaikan tiada lain sebagai upaya pencapaian ajaran Islam sebagai rahmat universal. Harapan ini menjadi cita-cita mutlak yang harus diresapi dan diinternalisasikan dalam setiap lubuk hati kaum muslimin dalam menciptakan kehidupan yang sesuai dengan syariat Islam. Namun, kenyataan terkadang tak sesuai dengan apa yang kita harapakan. Realitas menunjukan bagaimana kesulitan yang terkadang menjadi penghambat di kalangan muslim sendiri dalam mewujudkan aksentuasi dakwah universal ini dalam bingkai keumatan. Timbulnnya perselisihan, konflik dan terkadang perpecahan yang disebabkan furu'uddin (cabang-cabang agama) tak bisa di minimalisir. Masih banyak spirit lain yang tersisip secara disadari atau tidak dalam dakwah Islam selama ini. Hal ini yang perlu mendapat perhatian lebih dari para pelaksana dakwah dalam mewujudkan kedamaian semesta.

Inkonsistensi dalam dakwah menjadi faktor penghambat terciptanya dakwah universal yang selama ini kita harapkan. Inkonsistensi ini ada sebagai akibat dari ketidakselarasan antara konsepsi pemahaman dakwah baik dari para da'I amaupun madh'u dengan realitas pelaksanaan dakwah di lapangan. Masih adanya kepentingan di luar kepentingan esensi yang seharusnya menjadi spirit dakwah kita saat ini. Misalnya, kita cenderung bertindak tidak berdasar fitrah ketuhanan, melainkan lebih disemangati dan di dorong oleh motifmotif kemanusiaan, emosi-emosi sesaat dan ambisi kekuasaan yang ada di luar batas manusiawi.

Konsepsi dakwah selama ini dipandang sebagai kewajiban sebagian umat atas umat yang lainnya. Padahal sejatinya dakwah menjadi tonggak keumatan, menjadi spirit yang harus tertanam kuat dalam setiap ruh perjuangan seluruh umat Islam dimanapun kita berada. Jika doktrinasi pemahaman seperti ini tertusuk kuat dalam setiap jati diri 
seorang muslim, ditambah dengan kesadaran nyata dari setiap individunya, maka dengan sendirinya dakwah yang tercipta adalah dakwah sesuai dengan konteks ruang dan waktu, dakwah hasanah yang merepersentasikan keinginan setiap hambanya dalam mewujudkan kedamaian di seantero alam. Mengejawantahkan perikehidupan yang sesuai dengan syariat Islam sesuai dengan amanat Tuhan dalam Alqur'an Al Karim.

\section{Konsepsi Dakwah Di Kalangan Mahasiswa}

Ukuran tubuhmu tidaklah penting, ukuran otakmu cukup penting, dan ukuran hatimu itulah yang terpenting. Demikian ungkapan BC Gorbes seorang Psikolog Amerika. Ia memandang bahwa kehampaan yang selama ini tercipta di kalangan Ilmuwan Barat sejatinya terjadi karena kurangnya kepekaan mereka terhadap dimensi Spiritual yang menjadi fondasi kehidupan manusia. Disadari atau tidak nilai-nilai ilahiyah yang ada dalam diri manusia menjadi jembatan dalam mengembangkan potensi insaniyahnya. Dakwah sebagai kewajiban setiap muslim menjadi satu paradigma besar dalam menghantarkan kemaujudan Tuhan yang ada dalam diri setiap makhluk yang berakal menuju kedamaian abadi dalam diri dan lingkunganya. Dengan demikian, dakwah menjadi nilai mutlak yang tak bisa di pandang sebelah mata keutamaan dan kepentingannya oleh siapapun, dimanapun, kapanpun dan dalam konteks bagaimanapun.

Sebagaimana kita fahami bersama, dakwah adalah kewajiban setiap muslim sesuai dengan kadar yang melekat padanya. Dakwah bukan hanya milik segelintir ulama, bukan pula milik seorang cendikiawan muslim, tetapi dakwah adalah kewajiban seluruh umat untuk melaksanakannya. Tak terkecuali mahasiswa yang seringkali di pandang sebagai kaum intelektual, masyarakat akademik yang menjadi penerus estafeta perjuangan dalam menegakkan agama, bangsa dan negaranya. Sayangnya, pemahaman dakwah di kalangan mahasiswa belum merata di fahami. Banyak di antara mahasiswa yang masih kebingungan dengan konsepsi dakwah Islam. Peradigma dakwah yang selama ini berkembang ialah bahwa dakwah sebatas kewajiban ulama dalam menyebarkan pesan-pesan keIslaman. Akibatnya, banyak di antara mahasiswa yang acuh tak acuh dengan keutamaan dalam melaksanakan dakwah. 
Paradigma dakwah yang seringkali di fahami sebatas orasi mimbar menjadi salah satu faktor yang menyebabkan minimnya keinginan mahasiswa dalam melaksanakan dakwah. Artinya, paradigma dakwah semacam ini masih keliru, disalahfahmi dan belum ada keinginan untuk melangsungkan nilai-nilai esensial dalam dakwah tersebut. Maka dari itu, perlu adanya pendoktrinan kembali tentang substansi dakwah di kalangan mahasiswa sehingga mereka mengerti dan mau melaksanakan dakwah sesuai dengan kadar dan kemampuan yang ada.

Mahasiswa fakultas dakwah sebagai bagian dari entitas mahasiswa yang berdomisili di UIN sunan Gunung Djati Bandung menjadi rujukan dalam proses pengaktualisasian konsepsi dakwah dalam realitas kehidupan yang ada. Tentunya, konsepsi dakwah yang mereka fahami haruslah berbeda dari konsepsi dakwah yang ada. Proses pemahaman ini tidak terlepas dari upaya pentransferan gagasan dan konsepsi teoritis tentang paradigma dakwah di tengah kelangsungan hidup saat ini. Sebuah keironisan manakala mahasiswa dakwah tidak faham dengan paradigma dakwah yang seharusnya terfahamkan. Pasalnya, di kalangan mahasiswa dakwah, wacana-wacana tentang kedakwahan menjadi materi utama yang harus difahami sekaligus dilaksanakan sesuai dengan amanat Tuhan dalam kalam-Nya.

Fenomena yang terjadi saat ini sesuai pengamatan penulis ialah bahwa di kalangan mahasiswa dakwah sendiri konsepsi dakwah yang tersampaikan masih keliru. Dakwah yang difahami sebagai kegiatan orasi mimbar tampaknya masih melekat di sebagian besar pemikiran mahasiswa dakwah. Sungguh ironis. Selain itu, minimnya minat meraka (baca :Mahasiswa Dakwah) terhadadap pelaksanaan dakwah menjadi satu tanda Tanya besar bagaimana meningkatkan minat dan bakat dalam kegiatan dakwah di kalangan mahasiswa. Hal ini menarik untuk kita kaji, kemudian kita wacanakan dan tentunya solusi konstruktif seperti apa yang seharusnya kita ketengahkan dalam memandang gejala semacam ini.

\section{Paradigma Khithabah, Orasi Mimbar}

Khithabah atau dengan bahasa lain orasi keagamaan merupakan bagian dari dakwah. Khithabah sebagaimana kita fahami merupakan orasi keagaamaan yang dilakukan sebagai bagian dari upaya dakwah dalam menyebarkan pesan-pesan keIslaman yang bertujuan untuk menebarkan rahmat semesta. 
Sambas (2009: 113) dalam bukunya Dimensi Ilmu Dakwah mengemukakan bahwa formatisasi Ilmu dakwah ialah kajian seputar perilaku keIslaman dalam berIslam. Dimana formatif wacana ini dikategorisasikan menjadi bagian-bagian dakwah yakni Tabligh, Irsyad, Tathwir dan Tabdir. Khithabah adalah satu dari bagian proses tabligh yang mencoba menuangkan gagasan keIslaman yang disampaikan secara masif melalui media massa dalam arena komunikasi massa secara verbal.

Khithabah menjadi salah satu bagian dari metode tabligh yang umum dilakukan di kalangan da'i. khithabah dapat diartikan sebagai berkhutbah, berpidato, meminang, melamarkan, bercakap-cakap, mengirim surat, dll. Poerwadarminta dalam KBBI mengartikan khithabah sebagai sinonim dari kata berpidato terutama tentang uraian ajaran Islam. Sementara Harun Nasution menjelaskan bahwa khithabah ialah ceramah atau pidato yang mengandung penjelasan-penjelasan Islam tentang sesuatu atau beberapa permaslahan di hadapan khalayak ramai (Enjang dan Aliyudin, 2009: 57).

Dengan demikian dapat kita artikan bahwa khithabah merupakan kegitan ceramah atau orasi ilmiah tentang suatu permasalahan dalam kajian keIslaman (khitobuddin) yang disampaikan melalui media komunikasi massa, disampaikan dihadapan khalayak ramai dengan tujuan informatif, edukatif, rekreatif dan influence atau mempengaruhi khalayak, sehingga mengerti dan bertindak sesuai dengan apa yang kita harapkan.

Terdapat beberapa keunggulan dalam khithabah yang dapat dijadikan acuan dalam upaya Islamisasi tersebut (baca: dakwah). Adapun keunggulan khithabah yang penulis maksud di antaranya:

Pertama, khithabah sebagai bagian dari tabligh keIslaman mampu menghantarkan pendengar ke dalam balutan emosional tentang paradigma keIslaman saat ini. Hal ini sebagai bagian dari efektivitas dakwah dalam kegiatan tabligh.

Kedua, melalui kegiatan khithabah, efektivitas dakwah dengan frekuensi yang cukup signifikan begitu kentara. Bagaimana gagasan seputar keIslaman disampaikan dalam waktu yang relatif singkat, menghantarkan pesan dakwah kepada madh'u yang relatif luas.

Ketiga, umumnya pesan yang disampaikan dalam kegiatan khithabah merupakan pesan-pesan keIslaman yang relatif mudah 
dimengerti, difahami dan dilaksanakan madh'u. Ini menjadi keunggulan kegiatan khithabah sebagai upaya dakwah.

Keempat, khithabah melalui balutan informasi-edukasi-rekreasi menjadikan kegiatan dakwah sebagai kegiatan yang menarik, hal ini menjadi daya dorong pendeskripsian Islam sebagai agama yang ramah dan tanpa paksaan.

Kelima, melalui kegiatan khithabah upaya menangkis serangan barat yang anti Islam melalui pencitraan Islam dengan stigma negatif dapat diminimalisir. Dengan kata lain, dalam kegiatan khithabah tersisip upaya imagologis (pencitraan) tentang Islam dan umat Islam yang ramah, tanpa kekerasan dan peduli terhadap sesama.

Namun, tak dapat kita pungkiri pula bagaimana kegiatan khithabah yang ada tak jarang menjadi satu titik kelemahan yang harus dipikirkan solusi yang terbaik dalam menutup kelemahan pada kegiatan khithabah tersebut. Adapun kelemahan dalam kegiatan khithabah sebagaimana penulis amati di antaranya: bahwa melalui kegiatan khithabah seringkali pesan yang disampaikan bersifat one-way communication dengan respon yang relatif delayed. Sehingga pesan yang diterima madh'u sifatnya sesaat dan kurang emmasuki ranah emosiobnal. Artinya tak jarang madh'u hanya sebatas mendengarkan adapun esensi dari pesan tersebut kurang difahami. Selain itu, karena biasanya dalam kegaitan khithabah sifatnya figuritas, maka madh'u lebih melihat siapa yang menyampaikan pesan dakwah dibanding mengutamakan pesan dakwah itu sendiri. Sehingga, tak ayal seringkali kebablasan dalam upaya transfer gagasan tersebut.

Demikian paradigma khithabah dengan berbagai keunggulan dan kelemahannya. Terlepas dari itu semua, tampaknya khithabah tengah menjadi kebutuhan baru yang cukup membumi bagi masyarakat Idonesia. Ini kita lihat dari besarnya frekuensi kebutuhan akan nilai-nilai keIslaman dalam kehidupan sehari-hari. Di samping fenomena bermunculan da'i populer cukup kiranya menjadi sorotan dalam kegiatan khithabah tersebut.

\section{E. Minimnya Minat Khithabah Di Kalangan Mahasiswa}


Minimnya minat mahasiswa dalam kegiatan khithabah bisa disebabkan oleh kurangnya kepekaan mahasiswa itu sendiri terhadap kewajiban menyampaikan pesan-pesan dakwah di manapun mereka berada. Fenomena ini terjadi dikarenakan salah persepsi dalam menyikapi pentingnya melaksanakan dakwah di kalangan mahasiswa. Sebuah keironiasan manakala mahasiswa dakwah sendiri yang notabene mempelajari, mengkaji dan menganalisis permasalahan seputar dakwah tetapi kurang peka dalam proses aktualisasi dan aplikasi ilmu-ilmu dakwah dalam kehidupan nyata. Hal ini menjadi tolok ukur bagaimana mahasiswa memandang dakwah sebagai kewajiban parsial di kalaangan ulama dan tidak membuminya paradigma dakwah likulli zaman wa makan bagi segenap kaum muslimin di dunia.

Setidaknya ada beberapa faktor mengapa mahasiswa dakwah sendiri mempunyai minat dan bakat yang minim pada kegiatan khithabah. Di antaranya:

\section{Geliat Budaya Populer di Kalangan Mahasiswa}

Menggemanya budaya populer saat ini sebagaimana ungkapan Piliang (1991: 50) dalam pengantar buku Budaya Humanis yang pudar adalah bagian dari dampak perkembangan teknologi informasi yang tak terbendung di tengah kehidupan umat manusia. Budaya populer merupakan proses imagologis para pemangku kepentingan, dalam hal ini para kapitalis yang merasa penting mengupayakan nilai tanda dalam setiap dimensi kehidupan manusia. Parahnya, budaya populer ini mengantar manusia menuju gerbang hedonisme dalam gaya dan tata kelola pergaulan manusia. Dimana nilai prestise menjadi patokan dalam setiap aktivitas manusia. Artinya, utilitas atau nilai kegunaan menjadi sesuatu hal yang abstrak dan tergantikan oleh nilai prestise tadi. Ini sebagai dampak negatif dari semakin canggihnya teknologi manusia yang awalnya digunakan sebagai gadget yang memudahkan tetapi kenyataannya menjadikan manusia terkendali oleh mesin-mesin yang mereka ciptakan sendiri.

Semakin menggeliatnya budaya populer menyebabkan pergeseran orientasi di kalangan generasi Muda, tak terkecuali mahasiswa. Sejatinya, mahasiswa diperuntukkan sebagai penerus estafeta bangsa dalam memperjuangkan kesejahteraan masyarakat. Sementara dapat kita amati bagaiamana tata pergaulan mahasiswa yang mulai tergerus oleh budaya populer ini menjadi orientas prestise, ketika nilai-nilai asasi kehidupan mereka sebagai mahaisiwa bergeser dalam perwujudan masyarakat 
kelas atas yang kurang peka terhadap problematika bangsa ini (Ibrahim, 2008: 93).

Begitupun dalam kegiatan khithabah. Mahasiswa lebih senang melaksanakan kegiatan yang di pandang mempunyai nilai prestise tinggi dibanding menyuarakan pesan-pesan ilahi dalam upaya penyebaran ajaran keIslaman. Bisa jadi tergerusnya orientasi penyebaran pesanpesan Islam ini melalui kegiatan khithabah dikarenakan mahasiswa dakwah sendiri memandang bahwa kegiatan tersebut kurang mendatangkan profit dan tidak mempunyai nilai prestise yang tinggi di kalangan mahasiswa lainnya. Akibatnya, karakter yang mencuat di kalangan mahasiswa karena adanya budaya populer tersebut ialah menggeliatnya kebiasaan hidup enak, pergeseran orientasi dari semula mencari status ke mencari uang.

\section{Media Massa dan Keretakan Emosi}

Media turut mencipatakan keretakan emosi di tengah masyarakat, begitulah ungkapan Richard N.Restack (dalam Ibrahim, 2001: 43). Secara global, media massa mempunyai andil dan pengaruh yang cukup besar dalam kehidupan manusia. Dengan menggeliatnya teknologi informasi massa, kawula muda dalam hal ini mahasiswa sendiri banyak disuguhkan oleh berbagai panorama halusinasi realitas virtual yang pada akhirnya menghilangkan jati diri mahasiswa itu sendiri dan banyak menaruh harapan tanpa diiringi dengan ikhtiar yang mapan. John Naisbitt (2001: 23) dalam bukunya High Tech High Touch menyebutkan bahwa salah satu kemandegan adanya teknologi informasi massa ialah menyebabkan manusia masuk ke dalam Zona Mabuk Teknologi. Zona ini menjadikan manusia hilang kesadaran sosialnya, meretakan emosi simpatik dan empatinya dan seringkali menjadikan manusia bersikap individualistis. Merasa mampu mememnuhi kebutuhannya sendiri tanpa memerlukan bantuan orang lain. sehingga kepeduliaan terhadap sesama hilang menjadi ilusi-ilusi sesata dan pada akhirnya nuansa humanis pudar. Ini bertentangan dengan kewajiban dakwah yang mengharuskan manusia siapapun dirinya untuk senantiasa memperhatikan sesama, saling menasehati dalam kebaikan dan kesabaran (QS. 103: 03).

Spirit dasar yang menjadi ruh dalam khithabah adalah proses penyadaran diri akan realitas-realitas sosial di luar dirinya. Khithabah dijadikan sebagai sarana untuk saling memberikan pelajaran berharga antar sesama manusia, saling mengingatkan nilai-nilai kemanusiaan dan saling memberikan nasehat yang hasanah dalam dinamika kehidupan 
manusia. Sementara, karena geliat media massa dala berbagai content atau isinya yang kurang mencerminkan teladan keIslaman, apalagi bagi mahasiswa yang memasuki zona mabuk media massa sendiri secara psikologis menjadikan dirinya hilang kendali dan pada akhirnya menyebabkan keretakan emosi di tengah kehidupan masyarakat. Dengan kata lain, Mark Slouka bilang bahwa realitas nyata tergantikan oleh realitas buatan (masyarakat virtual).

\section{Motif Diri, Kurangnya Kemauan atau bahkan kemampuan}

Faktor selanjutnya yang menyebabkan mahasiswa minim dalam kegiatan khithabah ialah kurangnya kemauan dan kemampuan pribadi. Motif atau dorongan individu itu sendiri yang menjadikan dirinya mau atau tidak melaksanakan khithabah. Terkadang, motif diri menjadi elemen terpenting dalam melaksanakan suatu kegiatan. Bisa-tidaknya seseorang enjalankan satu kegiatan sangat tergantung dari besarnya minat dan keinginan yang ia miliki. Masalah kemampuan sebenarnya menjadi unsur kesekian. Terpenting adalah bagaimana mengembangkan kemauan dalam diri setiap mahasiswa untuk senantiasa menjalankan khithabah sebagai bagian dari kewajiban tabligh yang disandarkan kepada manusia.

\begin{tabular}{|l|l|l|}
\hline \multicolumn{1}{|c|}{$\begin{array}{c}\text { SDM/Motif } \\
\text { Diri }\end{array}$} & \multicolumn{1}{|c|}{ Mau } & \multicolumn{1}{c|}{ Tidak Mau } \\
\hline Mampu & $\begin{array}{l}\text { Mau + Mampu = Dahsyat } \\
\text { Motif diri kuat }\end{array}$ & $\begin{array}{l}\text { Tidak mau + Mampu = malas } \\
\text { Motif diri kurang }\end{array}$ \\
\hline Tidak Mampu & $\begin{array}{l}\text { Mau + Tidak Mampu }= \\
\text { Ada harapan } \\
\text { Motif diri antusias }\end{array}$ & $\begin{array}{l}\text { Tidak Mau + Tidak Mampu = } \\
\text { Tidak ada harapan } \\
\text { Motif diri hilang }\end{array}$ \\
\hline
\end{tabular}

Dari tabel di atas kita bisa melihat bagaiamana motif diri menjadi faktor yang penting dalam mengembangkan kegiatan khithabah di kalangan mahasiswa. Motif diri ini juga bisa diakibatkan karena beberapa hal, misalnya kurang kepercayaan diri dalam melaksanakan khithabah, merasa buyar materi kala menghadapi khalayak atau mustami, dan bisa jadi karena kurangnya minat baca dalam memperkaya khazanah keilmuan Islam dalam upaya penyampaian materi.

\section{Kurangnya Doktrinasi Keilmuan}


Internalisasi dan doktrinasi keilmuan menjadi sesuatu yang penting dalam mengembangkan minat dan bakat khithabah di kalangan mahasiswa. Selama ini, transfer gagasan tentang dunia dakwah baru sebatas pemahaman belum mamapu merasuki dunia alam bawah sadar mahasiswa sehingga tak jarang mahasiswa yang memandang rendah bagi mereka yang melaksnakan dakwah. Doktrinasi ini hubungannya dengan nilai tawar yang diberikan bagi mereka yang mau melaksanakan khithabah.

\section{Kurangnya Daya Tawar Dunia Khithabah}

Kurangnya daya tawar dunia khithabah ini berkaitan dengan unsur sosial dalam kehidupan manusia. Masih samarnya status seperti apa yang akan mereka peroleh jika menjadi penggiat dunia khithabah. Orientasi jurusan dalam hal ini perlu diperjelas kembali terkait dengan unsur profesionalisme dan profitable dari dunia khithabah. Karena sebagaimana kita ketahui bersama orientasi kelembagaan di era modern ini harus bisa menawarkan nilai-nilai prestise dalam kehidupan sosial.

\section{Tidak adanya award dari institusi yang bersangkutan bagi mereka Pecinta Khithabah}

Hal yang tidak bisa dinafikan juga ialah penghargaan atau reward bagi mereka yang mencintai dan melaksanakan khithabah. Sebagaimana Abraham H. Maslow bilang bahwa salah satu kebutuhan manusia adalah pengakuan dan penghargaan diri. Hal ini bisa dijaidkan sebagai nilai tambah dalam menyuarakan geliat khithabah di kalangan muda.

\section{Faktor Pemrasaran}

Sarana dan prasarana dalam praktek khithabah menjadi unsur yang cukup signifikan dalam mengembangkan minat mahasiswa terhadap khithabah. Kurangnya pemrasaran dari institusi pendidikan dakwah dalam mengembangkan minat khithabah ini menjadi salah satu faktor penyebab minimnya minat dan bakat mahasiswa dalam dunia khithabah. Bagaiamanapun dunia khithabah adalah dunia praktis. Jika mahasiswa dakwah hanya dijejali dengan sesuatu yang bersifat teoritik belaka niscaya sampai kapanpun aplikasi keilmuan dakwah tidak akan pernah mencuat. Dengan kata lain, sarana dan prasarana praktek menjadi sesuatu yang tak bisa dipandang sebelah mata. Mahasiswa membutuhkan room of theatre, ruangan praktek untuk mengembangkan minat dan kemampuan dirinya dalam dunia khithabah. 


\section{F. Penutup}

Demikian beberapa hal yang menjadi faktor minimnya minat dan bakat mahasiswa dalam kegiatan khithabah, hal ini sebagai upaya penulis untuk mendeskripsikan fenomena-fenomena keilmuan yang berdimensi sosial-keumatan dalam kegiatan dakwah yang sejatinya menjadi hal yang signifikan dalam perkembangan dan penyebaran pesan-pesan keislaman saat ini.

Sekali lagi, dakwah merupakan bagian dari ajaran dan kewajiban umat Islam untuk menebarkan keselamatan dan kedamaian universal di tengah kehidupan umat manusia. Kewajiban ini berlaku tidak hanya bagi kalangan ulama, melainkan seluruh umat Islam sesuai dengan kadar kehidupannya. Pun, objek atau mad'u dakwah itu sendiri berlaku tidak hanyauntuk umat Islam sendiri melainkan untuk seluruh umat manusia dalam berbagai kondisi dan konteks sosial yang ada.[] 


\section{DAFTAR PUSTAKA}

Madjid, Nurcholish. (2010). Islam Agama Kemanusiaan, Jakarta: Paramadina

Muthahari, Murtadha. (2006). Stop Anarkisme, Jakarta: Al-Huda

Nadjib, Emha Ainun. (2007). Tidak. Jibril Tidak Pensiun. Yogyakarta: Progress

Sambas, Syukriadi, dkk. (2009). Dimensi Ilmu Dakwah, Bandung: Widya Padjadjaran

Enjang dan Aliyudin, Mukhlis. (2009). Dasar-dasar Ilmu Dakwah. Bandung: Widya Padjadjaran

Slouka, Mark. (1991). Hilangnya Budaya Humanis, Bandung: Mizan

Ibrahim, Idy Subandi (ed.). (2008). Life Style Extacy. Yogyakarta: Jalasutra

Ibrahim, Idy Subandi. (2001). Hilangnya Nuansa Komunikasi Empatik. Bandung: Alkautsar

Naisbitt, John, dkk. (2001). High Tech High Touch. Bandung: Mizan 